\section{The Effectiveness of Google Earth in the Acquisition of Spatial Perception Ability in Social Studies Courses*}

\begin{tabular}{ll}
\hline Received: & 13 September 2018 \\
Revised: $\quad 15$ November 2018 \\
Accepted: $\quad 27$ February 2019 \\
ISSN: $1307-9298$ \\
Copyright @ 1 IEJEE \\
www.iejee.com
\end{tabular}

DOI: 10.26822/iejee.2019450788

\begin{abstract}
The aim of this study is to determine the effectiveness of Google Earth (GE) application in acquiring spatial perception ability in the fourth-grade social studies course. The research was carried out in a fourth grade of a primary school in the Demirci district of Manisa Province in the year 2015-2016 using embedded experimental design. During the five-week implementation process of the research, activities based on the GE practice were performed. A pre-test before the activities and a post-test after the activities were given to the students. In addition, semi-structured interviews were held with the students at the end of the implementation. The Wilcoxon test was used to analyze the data obtained from the achievement test, and the thematic analysis method was used to analyze the qualitative data. The results showed that there was a statistically significant difference between the pre- and post-test scores for the achievement tests. The students also stated that the activities based on the GE implementation increased their success and allowed them to gain spatial skills. In conclusion, the social studies course activities based on GE practice might have an important function for the students to gain spatial perception skills.
\end{abstract}

Keywords: Primary School, Social Studies Course, Spatial Perception Ability, Google Earth, Mixed Method

\section{Introduction}

In parallel with the development of technology in the twenty-first century, many innovations and changes have come up in the world in terms of social and economic aspects. Especially the continuously evolving computer and Internet technology have been used in all areas. This situation has shown its effectiveness in the field of education, and the traditional classroom model has been replaced by new learning environments. In the past, learning needs were met with chalk, blackboard, map, etc.; but today, interactive boards, projections, computers and even tablet computers are used. The integration of technology into education in line with the dynamics and needs of the developing community has become a necessity. Furthermore, with the development of technology, the change in society has also influenced social studies courses whose fundamental aim is socialization. The technology that integrates with the social studies course will help individuals to grow well equipped so that these individuals can supply the needs of the community by using the possibilities of the digital age. The social studies course aims at obtaining new knowledge and skills from the present information, based on a constructivist approach (Özkaral, 2015). In Turkey, the social studies curriculum was renewed in 2005, and the skills needed to be given to the students have been supplied through the new program. In the program, the skills to be given directly for the space perception are integrated with the technology to allow students to gain the skills.

Spatial perception is the process of determining the individual's own location in the space, creating information about the space in their mind, recognizing and understanding the space, finding a place, finding routes and describing places, depending on the route knowledge acquired through the recognition and understanding of the place (Köşker, 2012). It is also the ability to visualize the shapes of objects, to read the drawings related to space, to make various drawings on paper using the observations of spaces and to compare a place with the one drawn on paper (Erdoğan, 2008). Spatial thinking is one of the main forms of intelligence in modern societies; therefore, every individual needs the basic education to develop these necessary skills (Goodchild, 2008). Social studies courses help children to create space-related information and geography consciousness as well as to develop environmental understanding (Öcal, 2007). In parallel with all these explanations, it seems inevitable that, in addition to reflecting spatial perception and spatial thinking skills using the traditional paper and pencil approach, these skills should be used effectively in digital environments by different means and ways. However, it is observed that there is limited research on the acquisition of spatial perception skills of children at primary school age.

In the social studies courses of the primary school, the ability of spatial perception is among the skills to be taught directly. The activities that are prepared in accordance with the learning outcomes are utilized while teaching these skills. These activities are drawing a sketch, finding a route in a map, using a compass and learning the characteristics of weather forecast (Ministry of National Education [MoNE], 2005). It can be said that it is a necessity to take advantage of technology, especially the Internet, in teaching social studies. In addition to the opportunity to gain different perspectives by eliminating distances and boundaries in geographical perception, the Internet offers the opportunity to benefit from primary sources (Friedman \& Heafner, 2007). Social studies are taught to young generations to create opportunities to learn about the world in which they live. The information and communication technologies used in these courses enable students to get to know the world more easily (Acun, 2012). Because the social studies courses adopt the constructivist approach, its issues are intertwined with life, and the program's skills aim at enabling students to configure knowledge and to experience it, the social studies course is a program in which educa-

\footnotetext{
"This study was produced from the PhD dissertation titled "The Effectiveness of Google Earth in the Acquisition of Spatial Perception Ability in Social Studies Courses" submitted to Anadolu University Graduate School of Educational Sciences Program in Primary School Education (2017).

${ }_{a, * *}$ Corresponding Author: Ati Merç, Manisa Celal Bayar University, Faculty of Education, Manisa, Turkey. E-mail: ati.merc@cbu.edu.tr

Ali Ersoy, Anadolu University, Faculty of Education, Eskişehir, Turkey. E-mail: alersoy@anadolu.edu.tr
} 
tional technologies can be applied easily (Ersoy, 2013). The use of technology in social studies courses can increase the interest of students who are afraid of social studies courses (Heafner, 2004). Google Earth (GE), which is an application that shows the Earth on the Internet and can access to all residential areas, is an effective and technological tool in primary school social studies courses. GE also has a critical role in gaining spatial perception skills.

The GE application is a tool that transfers the real world into a three-dimensional web environment and provides the connection between the real and the virtual world by presenting tangible visuals to individuals (Jensen, 2010). Students can easily use GE in social studies courses due to accessibility and ease of use. GE also supports thinking and helps students learn about natural and cultural phenomena, and as an interactive tool, it helps teachers to give information about places. Students are more likely to learn about certain qualities of places and have the opportunity to observe the interaction between places and human relations (Patterson, 2007). Moreover, GE is a tool far beyond the traditional GIS applications as it allows for collecting information instantly from different sources (Goodchild, 2008). Teachers may plan lessons to help students understand the natural and cultural events (Guertin \& Neville, 2011). Awada and Diab (2018) have recently put forward that the GE application supports critical thinking and spatial analytical operations, and consequently, increases learner-centered learning and student motivation. Furthermore, focusing on asking students to use technology in order to give meaning to the world around them enable for new searches in the childhood and educational environments (Danby, Davidson, Ekberg, Breathnach, \& Thorpe, 2015). Xiang and Liut (2017) also state that the GE application gives students better opportunities to observe and interpret the changes in nature, and thus, it helps them understand the complex structure of changes. In this way, it incerases students' ability to define and analyze the spatial and time changes. An individual who looks at the environment from a cognitive standpoint can learn the places and objects around him/her in a more meaningful and useful way. There is a limited number of researches on the ability of space perception at the primary school level and on the "space perception problems" encountered in daily life, which triggered the present research. The main purpose of the present study, then, is to determine the effectiveness of GE application in acquiring spatial perception skills in social studies courses. For this purpose, the study sought the answers to the following questions:

-What is the level of spatial perception skills of the students before the GE application process?

-How was the training process of GE application carried out in acquiring spatial perception skills?

-What are teachers and students' views on the use of GE application in acquiring spatial perception skills?

-Did the GE application significantly affect the spatial perception skills of the students?

\section{Method}

Since both the qualitative and quantitative research methods are used for studying the development of spatial perception skills, the research was designed as a mixed model. In the mixed model, the qualitative and quantitative methods are used together to explain the research question in more detail (Creswell, 2009). The mixed model has four main designs: embedded, explanatory, exploratory, and parallel. There are two types of embedded design: embedded experimental design and embedded correlational design. The embedded experimental design was used in the research. Here, the main research question was answered with the quantitative data using the experimental design. The qualitative data, which were related to the experimental process, were collected during the implementation process (Plano Clark \& Creswell, 2015). Plano Clark, Huddleston-Casas, Churchill, Green and Garett (2008) stated that the embedded experimental design is useful for researchers who are willing to expand their quantitative data with qualitative data. The present study, therefore, was designed as a pretest post-test experimental design. The qualitative data, in this respect, were obtained as embedded into the quantitative data. In other words, the primary research tool is quantitative as the the qualitative data present a supporting and secondary point of view throughout this study. In Figure 1 , the embedded experimental design used in the study is described schematically.

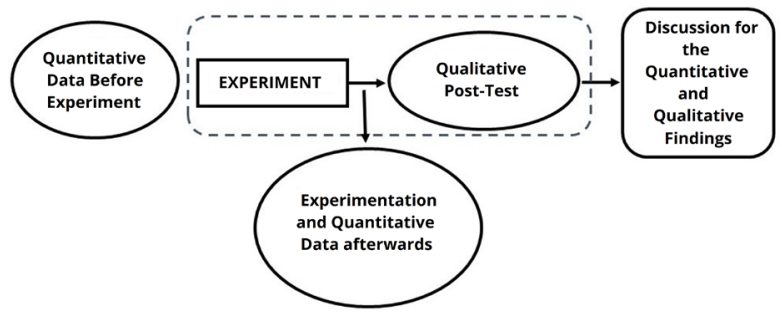

Figure 1. Embedded Experimental Model

As shown in Figure 1, if quantitative data is used to answer the main research question of the experimental design, and if qualitative data is used to search for an answer to the secondary research question in connection with the experimental process before and after the implementation, the design to be selected must be the embedded experimental design (Plano Clark \& Creswell, 2015).

\section{Participants and Research Context}

The research was conducted in the fourth grade of a primary school in Demirci, Manisa, Turkey during the fall semester of the 2015-2016 academic year. Criterion sampling was used in selecting the class used for this study. Criterion sampling is based on studying all contexts that correspond to a set of predefined criteria. The criteria mentioned here can be determined by the researcher or by a list prepared earlier (Yıldırım \& Şimşek, 2013). In the selection of the research school, it was determinative that the school administration and the teachers stated that they would participate voluntarily in the research, that they would allow the camera records and that the teacher had already done academic studies because he was the person to apply the implementation. The classroom organization and the physical appearance where the research was conducted is shown in Figure 2.

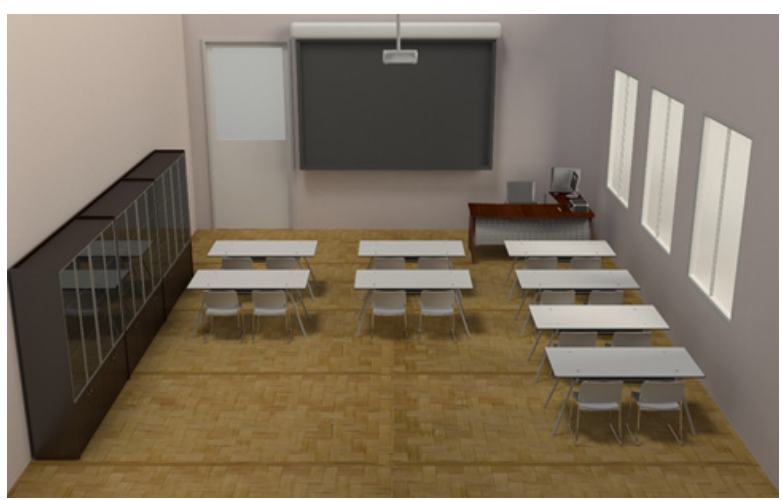

Figure 2. The Class Organization and Physical Appearance

The fact that no student had used GE, which was the basic application of the research, was also among the outstanding information. The research was carried out with 14 students in the classroom. Nine of the students in the class were male 
and five were girls. Nine students had computers at home, five did not have. Seven of them had an Internet connection, and the other seven did not have one.

\section{Experimental Process}

The implementation stage of the research was done by the teacher, and the researcher made the necessary explanations to the teacher. Then, the researcher started the observations in the classroom before the experimental procedure began. Following the observations, the personal information forms were given to the students. After giving the pre-test, the experimental process began.

The experimental process of the study was carried out for a total of five weeks. In social studies courses, the practice of developing spatial perception skills along with GE practices lasted for 10 hours of study in the "Where We Live" unit.

The experimental process started with the preparation of appropriate lesson plans after the researcher determined the learning outcomes and established the GE application to the computers used by the students in the course. While preparing the lesson plans, students' background knowledge was taken into account, and activities that would allow them to participate in the experiment process actively were prepared. In the activities of the lesson plans, the participation of the students as a full practitioner in the process was realized under the management of the teacher in accordance with the constructivist approach. Before the experiment, the class teacher was given the necessary instruction related to employing the lesson plans using the GE and each lesson plan was discussed thoroughly before the lessons were delivered. In this context, the teacher started the course by introducing the GE program to the students and then applied the course plans in accordance with the learning outcomes and activities. During the experimental process, the teacher ensured the full implementation of all plans and enabled all students to participate effectively in the activities. After the activities were completed, the post-test was applied, and finally, the semi-structured interviews were conducted.

\section{Data Collection Tools}

In the data collection process of the study, data collection tools for two different types of data were used according to the research questions because both quantitative and qualitative research methods were utilized. A personal data sheet, participant observation, and semi-structured interviews were used as the qualitative data while an achievement test, developed by the researchers, was used as the quantitative data. The achievement tests developed by the researchers were the pre-test and the post-test applied before and after the activities. To find the reliability of the achievement test, the test-retest method was conducted with 138 students in the 2014-2015 academic year. The test-retest score showed that the values of 10 people appeared as extreme values, so they were out of the process. Test-retest correlation was 0.73 . This value indicates that the achievement test is sufficiently reliable. The final version of the achievement test has 20 items in four factors: sign knowledge, sketch reading, region knowledge, and concept knowledge. Moreover, activities carried out during the experiment were video recorded. At the end of the application, semi-structured interviews were conducted with both the students and the teacher.

\section{Data Analysis}

An achievement test was used as the pre-test and posttest to determine the effectiveness of GE in acquiring spatial perception skills in social studies courses. The ob- tained data were analyzed using SPSS software. As there were fewer than 30 participants, Nonparametric Wilcoxon test was applied for repeated measurements to determine the difference between the pre-test and post-test scores of the students involved in the study.

The qualitative data were analyzed by the researchers using the thematic analysis. Thematic analysis is a method of detecting and analyzing content patterns in qualitative data. Braun and Clarke (2006) define thematic analysis as a method of analysis rather than a method of science as thematic analysis does not specify theoretical assumptions, appropriate research questions, or appropriate data collection methods. Thematic analysis can be used in a wide range of theoretical frameworks from basic experimental analysis to constructivist, critical analysis (Taylor \& Ussher, 2001).

\section{Finding and Results}

The quantitative findings obtained from the statistical analyses and the qualitative findings obtained from the participant observations, video recordings, and the interviews are presented below.

\section{Quantitative Findings}

In the study, a social studies course was conducted with the 20-item achievement test developed to determine the students' prior knowledge about their "Where We Live" unit.

Table 1. Pre-test Scores

\begin{tabular}{|c|c|c|c|}
\hline Score range & $f$ & Mean $(M)$ & $\begin{array}{c}\text { Standard } \\
\text { deviation }(s d)\end{array}$ \\
\hline $0-10$ & 0 & \multirow{11}{*}{35.429} & \multirow{11}{*}{8.582} \\
\hline $11-20$ & 1 & & \\
\hline $21-30$ & 2 & & \\
\hline $31-40$ & 6 & & \\
\hline $41-50$ & 5 & & \\
\hline $51-60$ & 0 & & \\
\hline $61-70$ & 0 & & \\
\hline $71-80$ & 0 & & \\
\hline $81-90$ & 0 & & \\
\hline $91-100$ & 0 & & \\
\hline Total & 14 & & \\
\hline
\end{tabular}

According to the data given in Table 1, the scores obtained from the achievement test before the courses prepared with activities of GE application were found as follows: $M=$ 35.429 ( $s d=8.582$ ). We observed that the students' prior information about the "Where We Live" unit is very low.

As a result of the experimental study on the acquisition of spatial perception skills of GE application, the achievement test was applied again, and the results are presented in Table 2.

According to Table 2, after the courses with GE activities, the scores obtained from the achievement test were calculated as $M=80.429(s d=3.956)$. When the scores obtained from the achievement test are examined, it is observed that the teaching and course activities for the students were very successful, and the learning increased. It was clear that almost all of the students increased their level of knowledge on the topics of "Where We Live" unit.

The Wilcoxon test was applied to identify the significance of the changes in the scores before and after the experimental procedure (Table 3). 
Table 2. Post-test Scores

\begin{tabular}{|c|c|c|c|}
\hline Score range & $f$ & Mean $(M)$ & $\begin{array}{c}\text { Standard } \\
\text { deviation }(s d)\end{array}$ \\
\hline $0-10$ & 0 & \multirow{11}{*}{80.429} & \multirow{11}{*}{3.956} \\
\hline $11-20$ & 1 & & \\
\hline $21-30$ & 2 & & \\
\hline $31-40$ & 6 & & \\
\hline $41-50$ & 5 & & \\
\hline $51-60$ & 0 & & \\
\hline $61-70$ & 0 & & \\
\hline $71-80$ & 0 & & \\
\hline $81-90$ & 0 & & \\
\hline $91-100$ & 0 & & \\
\hline Total & 14 & & \\
\hline
\end{tabular}

Table 3. Wilcoxon Test Results

\begin{tabular}{|c|c|c|c|c|}
\hline & & $N$ & $\begin{array}{l}\text { Mean } \\
\text { ranges }\end{array}$ & $\begin{array}{l}\text { Sum of } \\
\text { ranges }\end{array}$ \\
\hline \multirow{6}{*}{$\begin{array}{c}\text { Post- } \\
\text { test } \\
\text { Pre-test }\end{array}$} & $\begin{array}{l}\text { Negative } \\
\text { Ranges }\end{array}$ & $0^{a}$ & .00 & .00 \\
\hline & $\begin{array}{l}\text { Positive } \\
\text { Ranges }\end{array}$ & $14^{b}$ & 7.50 & 105.00 \\
\hline & Equals & $0^{c}$ & & \\
\hline & Total & 14 & & \\
\hline & $Z$ & $3.296^{b}$ & & \\
\hline & $p$ & $.001^{* \star}$ & & \\
\hline
\end{tabular}

The number of positive ranges of students (14) is higher than the number of negative ranges $(0)$, which can be seen from Wilcoxon test results. The Wilcoxon $Z$ value $(Z=-296)$ which tests whether this difference is meaningful, is significant at 0.01 level. The post-test scores of the students involved in the study are significantly higher than the pretest scores. In other words, the experimental process increased students' scores. This change is shown in Figure 3 below.

The results of the analyses of both the pre- and post-test scores for the four sub-factors of the achievement test are presented in Table 4.

As Table 4 shows, the pre-test score average of the sign knowledge factor (question 18, 20, 7, 3, 2) was calculated as $(M=3.9286),(s d=3.33891)$. While students can get 25 points from the pre-test questions, they have a maximum score of 11 and a minimum score of 0 . The post-test point average of sign knowledge factor was calculated as ( $M=$ 19.8571), ( $s d=2.76954)$. The students received 25 points from the post-test questions, and they received 15 points as a minimum. The average of pre-test scores of sketch reading knowledge factor (question 15, 1, 19, 17,6) was calculated as $(M=5.3571)$, ( $s d=2.89846)$. While students can get 25 points from the pre-test questions, they have a maximum score of 11 and a minimum score of 0 . The post-test score average of sketch reading knowledge factor was calculated as $(M=19.1429),(s d=2.76954)$.

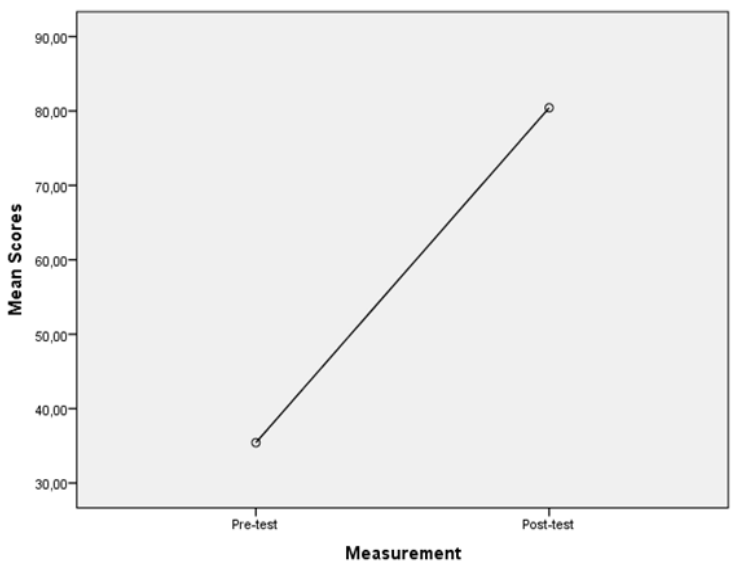

Figure 3. Pre-test and Post-test Measurement Chart of Experimental Process

The students received a total score of 23 and a minimum score of 15 from the post-test questions of sketch reading knowledge factor. The pre-test score average of the concept knowledge factor (questions 9, 14, 5, 11, 8, 12) was calculated as $(M=18.2143)$, $(s d=4.64391)$. While the students can get 30 points from the pre-test questions of the concept knowledge factor, they have a maximum of 25 points and a minimum of 10 points. The post-test score average of concept knowledge factor was calculated as $(M=27.1429),(s d=2.56776)$. The students received 30 points, which is the full score from the post-test questions of a concept-information factor, and the minimum score of 25 points. The region knowledge factor (questions $10,4,13,16)$ of pre-test score average was calculated as $(M=7.5000)$, $(s d=3.25222)$. While the students can get 20 points from the preliminary test questions, they have a maximum score of 15 points and a minimum of 5 points. The post-test score average of region knowledge factor was calculated as $(M=14.2857)$, ( $(s d=3.31497)$. The students took the full score of 20 points and the minimum

Table 4. Descriptive Statistics of Scores at the Level of All Sub-factors

\begin{tabular}{cccccccccc}
\hline & \multicolumn{9}{c}{ Pre-Test } \\
& $N$ & Mean & sd & Min. & Max. & Mean & sd & Min. & Max. \\
\hline Sign Knowledge & 14 & 3.9286 & 3.339 & 0 & 11 & 19.8571 & 2.770 & 15.00 & 25.00 \\
\hline $\begin{array}{c}\text { Sketch Reading } \\
\text { Knowledge }\end{array}$ & 14 & 5.3571 & 2.899 & 0 & 11 & 19.1429 & 2.770 & 15.00 & 23.00 \\
\hline $\begin{array}{c}\text { Concept } \\
\text { Knowledge }\end{array}$ & 14 & 18.2143 & 4.644 & 10 & 25 & 27.1429 & 2.568 & 25.00 & 30.00 \\
\hline $\begin{array}{c}\text { Region } \\
\text { Knowledge }\end{array}$ & 14 & 7.5000 & 3.252 & 5 & 15 & 14.2857 & 3.315 & 10.00 & 20.00 \\
\hline Total & 14 & 35.429 & 3.956 & 15 & 47 & 80.429 & 3.956 & 74 & 88 \\
\hline
\end{tabular}


score of 10 points from the post-test questions of region knowledge factor.

The results of the analysis of whether there is a significant difference between the pre-test and the post-test at the total score level displaying the changes of the students scores belonging to the sub-factors before and after the experimental process are given in Table 5 below.

Table 5. Table of Range Differences in All Sub-factors

\begin{tabular}{|c|c|c|c|c|c|c|}
\hline & $Z$ & $p$ & & $N$ & $\begin{array}{l}\text { Mean } \\
\text { ranges }\end{array}$ & $\begin{array}{l}\text { Sum } \\
\text { of } \\
\text { ranges }\end{array}$ \\
\hline \multirow{4}{*}{$\begin{array}{c}\text { Sign } \\
\text { knowledge } \\
\text { Post-test } \\
\text { - Sign } \\
\text { knowledge } \\
\text { Pre-test }\end{array}$} & \multirow{4}{*}{-3.301} & \multirow{4}{*}{$.001^{*}$} & $\begin{array}{c}\text { Negative } \\
\text { Ranges }\end{array}$ & 0 & .00 & .00 \\
\hline & & & $\begin{array}{l}\text { Positive } \\
\text { Ranges }\end{array}$ & 14 & 7.50 & 105.00 \\
\hline & & & Equals & $0^{c}$ & & \\
\hline & & & Total & 14 & & \\
\hline \multirow{4}{*}{$\begin{array}{l}\text { Sketch } \\
\text { Reading } \\
\text { Post-test } \\
\text { - Sketch } \\
\text { Reading } \\
\text { Pre-test }\end{array}$} & \multirow{4}{*}{-3.309} & \multirow{4}{*}{$.001^{*}$} & $\begin{array}{c}\text { Negative } \\
\text { Ranges }\end{array}$ & 0 & .00 & .00 \\
\hline & & & $\begin{array}{l}\text { Positive } \\
\text { Ranges }\end{array}$ & 14 & 7.50 & 105.00 \\
\hline & & & Equals & 0 & & \\
\hline & & & Total & 14 & & \\
\hline \multirow{4}{*}{$\begin{array}{l}\text { Concept } \\
\text { knowledge } \\
\text { Post-test } \\
\text { - Concept } \\
\text { knowledge } \\
\text { Pre-test }\end{array}$} & \multirow{4}{*}{-3.228} & \multirow{4}{*}{$.001^{*}$} & $\begin{array}{c}\text { Negative } \\
\text { Ranges }\end{array}$ & 0 & .00 & .00 \\
\hline & & & $\begin{array}{l}\text { Positive } \\
\text { Ranges }\end{array}$ & 13 & 7.00 & 91.00 \\
\hline & & & Equals & 1 & & \\
\hline & & & Total & 14 & & \\
\hline \multirow{4}{*}{$\begin{array}{c}\text { Region } \\
\text { knowledge } \\
\text { Post-test } \\
\text { - Region } \\
\text { knowledge } \\
\text { Pre-test }\end{array}$} & \multirow{4}{*}{-2.961} & \multirow{4}{*}{$.003^{*}$} & $\begin{array}{c}\text { Negative } \\
\text { Ranges }\end{array}$ & 1 & 4.00 & 4.00 \\
\hline & & & $\begin{array}{l}\text { Positive } \\
\text { Ranges }\end{array}$ & 12 & 7.25 & 87.00 \\
\hline & & & Equals & 1 & & \\
\hline & & & Total & 14 & & \\
\hline
\end{tabular}

As a result of the Wilcoxon test (Table 5), the number of positive ranges of students (14) is more than the number of negative ranges of students ( 0 ). The Wilcoxon $Z$ value ( $Z=$ -3301), which tests whether this difference is significant, is significant at 0.01 level. The student's post-test scores for the sign knowledge is higher than the pre-test scores. In other words, the experimental process increased the student's sign knowledge sub-score points.

As can be seen in the result of the Wilcoxon test (Table 5), the number of positive ranges of sketch reading sub-factor (14) is higher than the negative ranges (0). The Wilcoxon $Z$ value $(Z=-3.309)$ is significant 0.01 level. The post-test scores of the students' sketch reading are significantly higher than the pre-test scores. We can say that the experimental process increased the sketch reading sub-factor scores of the students.

The number of positive ranges of concept knowledge sub-factor is higher (13) than the negative ranges (0). The Wilcoxon $Z$ value $(Z=-3.228)$ is significant at 0.01 level. The post-test scores of concept knowledge are significantly higher than the pre-test scores. In other words, the experimental process increased the students' concept knowledge sub-factor scores.

As can be seen in the result of the Wilcoxon test (table 5 ), the number of positive ranges of region knowledge sub-factor is higher (12) than the negative ranges (1). The Wilcoxon $Z$ value $(Z=-2.961)$ is significant at 0.03 level
The post-test scores of region knowledge are significantly higher than the pre-test scores. Thus, experimental processing increased students' region knowledge sub-factor scores.

According to the results of the achievement test, which constitute the quantitative part of the study, the students' spatial perception skills increased significantly with the application of GE-based activities.

\section{Qualitative Findings}

The semi-structured interviews were held with the students and teacher in the classroom where GE-based activities were implemented. Through the thematic analysis of the data obtained from the interviews, the main theme of "Google Earth Application in Social Studies Courses" was determined. Within this main theme, "Spatial Perception, Social, Emotional and Technological Dimensions" were classified as four sub-themes. In the interpretation of the themes, direct quotations were made to the teachers' responses, to interview questions, and to video recordings. The themes are given in the form of a puzzle (Figures 4 and 5), and the parts forming the sub-themes are shown in two ways. Regarding the spatial perception dimension, red color was used in the puzzle form, and the yellow color was also used because it was thought that the situations forming the technological, emotional and social dimensions could affect each other. The theme of "Google Earth Application in Social Studies Courses", which is the main theme with orange color, is reached with the integration of all parts. Based on the opinions of teacher and students, the contents of technological, emotional and social dimensions are thought to transmit information to each other.

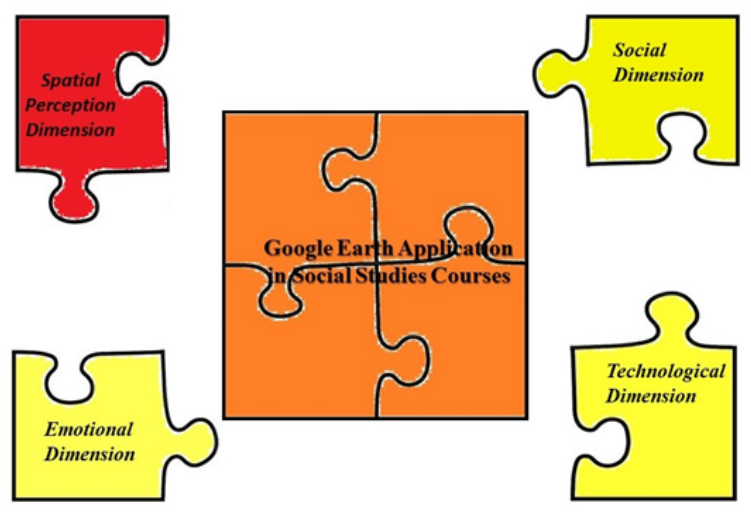

Figure 4. The Dimensions of GE Implementation in Social Studies Courses

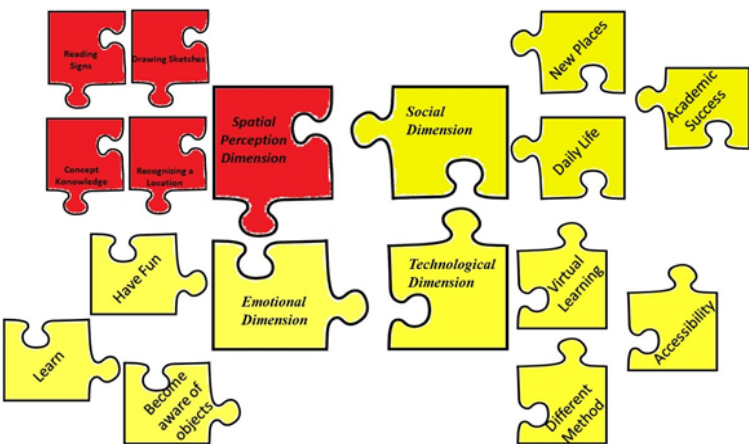

Figure 5. The Lower Dimensions of GE Implementation in Social Studies Courses

\section{Spatial Perception Dimension}

The theme of the application of GE in social studies courses detected by the interviews with the teacher and stu- 
dents after the implementation and by video recordings of the classroom is the dimension of spatial perception. This dimension is more concerned with the academic skills and competencies that students gained. These are conceptual knowledge of the ability for drawing sketches, reading signs, recognizing a location and perceiving space. They also fit well with the skills used in activities related to spatial perception skills, including the identified factors of the achievement test that form the quantitative part of the study.

The classroom teacher explained that the activities carried out with GE practice directly affected spatial perception skills and that the direction-finding skills, direction-describing skills, shortly, space perception skills increased, and that students were able to find places of interest in the world and that they had a lot of fun in doing these things and developed themselves. In this interview, the teacher made evaluations based on the views given below within the scope of the spatial perception dimension:

Space perception remains as a little abstract concept in primary schools. Well! I am now the teacher of the fourth grades, the fourth grades are the highest grade of primary school, and that is, they are in the closest age group to the abstract perception period. But, of course, children's learning by seeing things in three dimensions contributes more to their learning, that is, it is easier for them to perceive something they see and live in, thus they can transform it into behavior, being more effective rather than teaching it abstractly. For example, if they are curious about the Eiffel Tower in Paris, they go immediately. They find the Eiffel Tower and see its photographs, can find important buildings, and can interest in the weather there. I mean, they felt like traveling there, and they had a good time. I can notice that their concepts of direction enhanced very nicely. I think we have seen it in the post-tests. When we talk about direction concepts in routine courses, I can feel that the subject is easily understood. For example, when describing a place, "here you will go, will turn this way from the grocery store" expressions changed, and the children began to use statements such as "You will turn to the south from the mosque, you will turn to the north" (Interview with the teacher, 20 Jan 2016).

After using GE, the students stated that they could read the signs they encountered in daily life, they learned the concepts that created spatial skills, they could perceive and find the location of their destination, and they could easily sketch the places they knew. Examples of some students' opinions on this subject are given below.

I learned directions, I learned weather, and for example, I can learn the weather from meteorology. I knew a little about the directions but began to know much more. I've seen the weather, and I've seen everywhere I wonder. Here it is... In my daily life, for example, when I am lost, I find my ways with the directions, and for example, I can look at the weather when I go out (Interview with Haşim, 13 January 2016).

For example, my painting was bad, I could not draw a sketch, but I was able to draw a sketch with GE. When describing the location of my house I used to have difficulty, I'm doing it right now with GE (Interview with Melike, 14 January 2016).

Haşim stated that his direction concepts developed with the GE application, his knowledge of locations increased, he can use the direction concept better in daily life and learn weather events easily. Melike shows that they made progress in drawing sketch, but also that they increased their concept knowledge by associating the sketch with a bird's eye view. Melike also stated that her ability to find direction was better than the past and she could describe direction more easily.

When interviews and video recordings are examined, it is found that the use of GE in social studies course contributes to sketching, direction and location skills, conceptual information including knowledge of signs and natural or human-made spaces, and the sign knowledge consisting of weather and symbols. It is supported by the opinions of the teacher that the use of GE directly contributes to the spatial perception skills, and the students showed this with practical examples. It is seen how useful GE practice is from the sketches that students drew before and after by using GE in social studies courses (Figure 6).

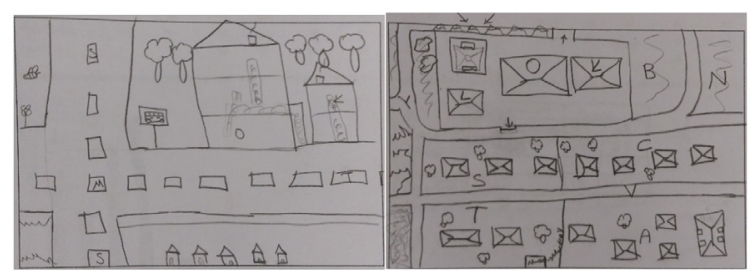

Figure 6. Sketches Before and After the Training

\section{Emotional Dimension}

One of the reflections of the GE application emerging after the analysis of the opinions of teachers and students and video recordings of the application is the emotional dimension. After the use of GE in social studies course, students have fun, learn, and become aware of the objects, settlements around them, which constitute the issues of emotional dimension. The teacher and students were very happy and entertained while using GE application, and they also saw images of different assets and places and learned new information. During the interview, the class teacher stated that the application of GE was very comprehensive, that it excited the students and attracted their attention, that it enabled them to access all kinds of information so that the courses were efficient. The teacher's opinion on this subject is given below:

When I evaluate the GE software, I can say these. GE software is a very comprehensive software and attracted the attention of children. They were thrilled when I first talked about it. Their using computers, learning how the program works, mastering the program, getting access to any kind of information also excited them. The course was efficient, the program was nice from that point of view (Interview with teacher, 20 January 2016).

It was observed that the students were very excited to take lessons with an application they had never seen before. This situation has become a state of learning by having fun with new learning as the program is used. Learning while having fun facilitated the teacher's work as well as ensuring that the information became permanent. The statements reflecting the students' thoughts on this subject are as follows:

It was a little surprising to me and it was pretty. I think it was a good way to learn the place we live. I learned a lot (Interview with Deniz, 12 Jan 2016).

It was so beautiful, I had a lot of fun. It was so beautiful to look down on the world like this. It was a lot of fun (Interview with Sena, 12 Jan 2016).

It was very beautiful, very excited. It was very educative. Everyone had a lot of fun (Interview with Ilayda, 12 Jan 2016).

Deniz also said that it was very surprising and fun to learn about GE software and that it was very effective in the learning of the "Where We Live" unit. Sena also stated that GE software is very good and that it is fun to look at the world from the top. Ilayda stated that the GE application was very exciting and enjoyable and that it has educational features.

Students lack information because they can't go to some of the places around them and in nearby cities. For example, Rumeysa, who did not know that Pamukkale was 
white [an ancient place in Denizli, Turkey], learned its color when she saw its photograph with the GE application. Through GE application, students improved their ability to learn shape, color, and orientation of important places that they formerly are not aware of, by structuring their old knowledge, this inference can be reached through the interviews or video recordings. The following dialogue was between the teachers and students in the process of the course with the GE application:

\section{Rumeysa: Teacher! Is this Pamukkale?}

The teacher: Let me look, yeah right.

Rumeysa: I've never been here before, it's so white.

The teacher and students mentioned that GE practice was fun and that learning became effective while having fun. With the GE application, students noticed the places that they knew but did not see it. Therefore, the GE application mobilized students' emotional responses.

\section{Technological Dimension}

One of the reflections of the GE application emerging after the analysis of the video recordings and the feedback from the teachers and students participating in the application is the technological dimension. After using GE in social studies course, having easy access to the information that students and teachers need, using a computer in addition to classical textbooks, in other words, teaching with a different method, and learning in virtual environment constitutes the subjects of technological dimension. The GE application, which was used as a different method, motivated the students and contributed to their learning. With the use of GE in social studies course, the classroom teacher used technological materials instead of traditional ways of routine teaching. The courses have become more efficient and students have used the application themselves. Thus, the courses became appropriate to the logic of constructivist social studies education. At the same time, the teacher stated the students' acquisitions from the social studies course as follows:

We went out of routine. For example, when we follow the textbook, I was giving kids a reading paper the day before, and I was giving them a job so that they came prepared. After that, we were studying. We were solving the necessary questions. They got out of the routine. They used it themselves, so we just guided them. It was very productive and effective in that respect. According to the location of their home or schools, different institutions, as I said, they can express the direction of different places in the form of the south, north etc. They couldn't say it if we'd just follow, you know, the regular textbook. They could only say the directions of the north-south according to the sunrise. But when they state directions to a place from their location, they could not use expressions like the south and the north. But now they are doing it with $G E$, they are doing it clearly (Interview with the teacher, 20 January 2016).

For students who met with a new tool in addition to the books used in the lessons, the computer and GE application has become a different method. The ability to go to any place they want and to see there has benefited both the teacher and the students in terms of accessibility. By using the computer, the virtual learning provided by digital images has been realized. Aslı stated that she had developed academically, that after using GE she could solve questions, and that using computers in lessons is a new method. We observed that students were motivated when they were out of classical methods. Melike and Basri expressed their views that GE practice was a new method used in social studies course, and that they were now working on a computer with GE application while they were only working on books and project homework before. The views of these students are given below:
The computers came. We've learned everything from $G E$, for example, we could never see our world, but now we've seen it. I can now answer when the teacher asks questions (Interview with Aslı, 13 January 2016).

We used to do it from the Book, but now we can use the computers sometimes (Interview with Izzet, 14 Janary 2016).

In the past, our materials were different, now we have used technological products (Interview with Melike, 14 January 2016).

In social studies, we used to do books and project homework. Now we are doing it on the computer, I think this is the changed thing (Interview with Basri, 12 Jan 2016).

The GE application used in social studies course facilitated the accessibility of students to information. Unlike classical classroom tools, a method that follows the latest developments of technology brings the advantages of technological dimension to the students by going beyond routine and learning with the introduction of reality within the virtual environment. Students can access information about routes, directions, different locations and weather more quickly and easily, and it can be concluded that this contributes to the learning process of students.

\section{Social Dimension}

The last reflection of the GE application emerging after the analysis of the opinions and video recordings of the teacher and students participating in the application is the social dimension. Following the use of GE in the social studies course, the students and teacher found important historical artifacts in their surroundings and places all over the world. The students got the information they need and succeeded in lessons and exams and completed their own deficiencies compared to the other students.

The teacher mentioned that the students understood about the GE activities and that they were doing activities as from school-to-house and from house-to-school as the orientation activities. The teacher stated that the students found the location of important places, were able to understand and knew about everywhere they interested:

The children understood well the subject, and after learning how to handle and where to find them, they were able to find all the centers they wondered about in the world. They found the places, they could find the directions, their homes, and their schools. They were able to find institutions such as governmental institutions in Demirci [The district where the students lived]. Now, when someone is asking for directions, the kids can easily express directions like "go that way to the north or south". Well, it was productive at that point. For example, they were curious about the Great Wall of China. They were wondering about Pamukkale, some saw their photographs the first time, and it was very positive in this respect as if traveling the world. So, we can count many positive aspects (Interview with teacher, 20 January 2016).

Mehmet and Rumeysa stated that they discovered new places, visited different countries virtually and learned about new places. Rumeysa said she felt like she was driving around the world with GE applications. She mentioned the availability of GE in daily life by stating how realistic it is. Haşim, Semih, and Izzet stated that their success increased with the GE application, that they could draw more easily, knew the ways they used to go home from school and travel to the city.

We searched the cities and we tried to find other ways in the city. We traveled with it everywhere and saw the natural and human-made places. It was so nice to find grades, we just could learn better when we looked at it, it would be better to look at these places through the GE instead of looking at it on TV. I think my performance has changed. I used to stir North-East or North-West, now I am not stirring (Interview with Mehmet, 12 January 2016)). 
With the aid of the GE application, I've seen things that I had never seen before. I felt like I was driving. GE application has helped us learn more easily. If I ask how the weather is, it shows immediately. I learned easier because it helps in everything (Interview with Rumeysa, 14 January 2016).

Some of my answers in the exams were wrong. Wrong answers don't come out anymore even about the weather. In my daily life, for example, I can find directions when I was lost, and for example, I can look at the weather when I am going to go out. We also looked at the bird's-eye sketch in the GE program. Then we can do it with our book without the GE program (Interview with Haşim, 13 January 2016).

Students have seen and identified new places they see on TV, in books, or hear from others, by GE application and satellite photos. The place each student wants to see changed according to their interests and needs. Especialy when boys were searching to see the country of footballers and basketball players, girls wanted to see cities like Paris, Venice. This shows that the desire to learn new places is an important issue within the social dimension. Increasing the students' success in the classes allowed them to acquire a special place among others socially. After the implementation of GE, the students' success in the courses contributed to the development of their self-confidence, as well as to the necessary information in daily life like learning weather, finding location, etc. From here, it can be assumed that the application of GE plays an important role in the class in terms of socialization.

In general, we can conclude that the issues in social dimension have an important place in eliminating the individual needs of the students and that employing the GE in social studies courses can contribute positively to the development of the students.

\section{Results and discussion}

In the social studies course, the recruitment of activities based on GE implementation was observed to improve the students' space perception skills. Statistically significant differences were found between the pre-test and post-test scores of the students who participated in the application. This finding is consistent with the results of some research conducted with GE application (Xiang \& Liut, 2017; Demirci, Karaburun, \& Kılar, 2013; Koçak, 2013; Ögütveren, 2014; Thankachan \& Franklin, 2013; Westgrand, 2010; Qiu, 2006). In this context, it can be said that the activities based on the GE application used for improving the spatial perception skills of students in the socia studies courses are effective.

In the research, the spatial perception skill, the ability to read the signs, drawing the sketch, the spatial conceptua knowledge skills and the location perception skills of the students were determined to increase. These results were similar to previous research (Blank, Almquist, Estrada \& Crews, 2016). In their study, Ratinen and Keinonen (2011) use the GE to improve teacher candidates' geographic thinking levels, despite the development of the geographical level of teacher candidates, map analyzing and geographical data still remain difficult for them. These results include similarities and differences with our results. It can be assumed that the differences arise from the level difference between groups and that issues and learning outcomes occurred as a result of the effects of national differences and the measurement instruments.

Within the scope of GE practices, the teacher and students expressed positive views on the subjects and contents of the activities. The students, who noticed their surroundings, stated to have fun and learn during the activities prepared with GE application. The teacher said that the cours es were very different, the students' motivation increased, the students had a lot of fun, they were interested in the course and their learning process was successful. The teacher said that the students noticed the environment and world since GE is a very comprehensive application. Students and teachers expressed views that they have learned new places with GE practice, they have easy access to their places of interest, and that they have developed themselves in sketching and finding directions. Öcal (2007) stated that the students had great difficulties in spatial cognition about their immediate environment and that they had problems in describing their school environment and their place of residence, but they had more information about distant cities and countries. This can help us achieve the conclusion that the GE application is an important tool for the development of spatial perception. Some studies concluded that the GE application is more effective and useful than the traditional maps, and the issues in the social studies curriculum are appropriate for GE use (Demirci \& Karaburun, 2011; Edstrom, 2013; Karakuş \& Oğuz, 2013, Xiang \& Liut, 2017). We observed that the technological materials used in GE application in the classroom were very different from the course materials and methods used in the past, thus increasing the level of motivation and learning of the students. Teaching the concept of spatial perception, an abstract concept, with GE practice made the issue to become more concrete. The teacher who stated that the three-dimensional real images contributed to learning through seeing and practicing by the students reported that the students transformed knowledge into behavior with virtual learning, which was also observed in the video recordings.

Due to the easy accessibility of the GE application, students can use its required aspects such as weather, roads and sketch in daily life and can reach a quick conclusion. Students who are looking for a place they are interested in can easily find that place and see all the features of the GE application and reach the information they need. The fact that GE application, which is an application that can be used with computers, includes information about all over the world, allowed us to think that it will help social studies course not only due to ease of use but also due to the accessibility of information. We observed that the students, who have difficulty finding and describing their directions before using GE practice, could find the directions and their positions easily, and for the questions asked about their directions, they easily and accurately used the concepts of direction that is in the scope of social studies course acquisitions. The teacher also expressed views that the students' development in using the concepts of direction and location after GE implementation increased.

According to the results of the research, the use of GE has enabled students to develop positive attitudes towards social studies course and to increase their participation and motivation. For this reason, the GE application can be used for all learning outcomes that are consistent with the logic of the education program. Teachers' use of GE in classrooms will help students actively demonstrate themselves in the classroom, and it will help to transmit the information directly to the actions. Therefore, teachers and school administrators should give the necessary information and guidance so that technological applications such as GE application can be used in the courses. Problems caused by a lack of technological infrastructure in most schools can lead to difficulties in the use of new applications such as GE. Therefore, teachers hold the main responsibility. They must communicate with the necessary institutions and work for the establishment of the infrastructure; they can also use individual technological materials with students at the school. 


\section{References}

Acun, i. (2012). Bilgisayar destekli öğretim uygulamaları. C. Öztürk (Ed.). Sosyal bilgiler öğretimi (3rd ed.) (pp. 343-365). Ankara: Pegem.

Awada, G. \& Diab, H. (2018). Effect of Google Earth and Wiki Models on Improving the Oral Presentation Skills of EFL Learners. International Journal of Teaching and Learning in Higher Education (IJTLHE), $30(1), 36-46$.

Blank, M. L., Almquist, H., Estrada, J., \& Crews, J. (2016). Factors affecting student success with a google earth-based earth science curriculum. Journal Science Educational Technology, 25, 77-90.

Braun, V. \& Clarke, V. (2006). Using thematic analysis in psychology. Qualitative Research in Psychology, 3(2), 77-101.

Creswell, J. W. (2009). Research design: Qualitative, quantitative, and mixed methods approaches. (3rd ed.). Thousand Oaks, CA: Sage.

Danby, S., Davidson, C., Ekberg, S., Breathnach, H., \& Thorpe, K. (2016). 'Let's see if you can see me':making connections with Google Earth ${ }^{\mathrm{TM}}$ in a preschool classroom. Children's Geographies, 14(2), 141-157. doi:10.1080/14733285.2015.1126231

Demirci, A., \& Karaburun, A. (2011). CBS, GPS ve Google Earth teknolojilerinin coğrafya derslerinde kullanımı. Marmara Coğrafya Dergisi, 24, 99-123.

Demirci, A., Karaburun, A., \& Kılar, H. (2013). Using Google Earth as an educational tool in secondary school geography lessons. International Research in Geographical and Environmental Education, 22(4), 277 290.

Edstrom, J. A. (2013). Comparative analysis of Google Earth versus traditional paper maps in middle school earth science education (Unpublished Master Thesesis). Oregon State University, USA.

Erdoğan, i. (2008). Öğrenciyi ve programı anlamaya yardımcı ilköğretim veli kılavuzu. Ankara: Milli Eğitim Yayınları.

Ersoy, F. (2013). Teknolojinin tarihçesi ve eğitimde kullanımı. Sever, R., \& Koçoğlu, E., (Ed.). Sosyal bilgiler öğretiminde eğitim teknolojileri ve materyal tasarımı, (pp. 21-36). Ankara: Pegem.

Friedman, A., \& Heafner, T. (2007). You think for me, so I don't have to. Contemporary Issues in Technology and Teacher Education, 7(3), 199-216.

Goodchild, M. F. (2008). The use cases of digital earth. International Journal of Digital Earth, 1(1), 31-42.

Heafner, T. (2004). Using technology to motivate students to learn social studies. Contemporary Issues in Technology and Teacher Education, 4(1), 42-53.

Jensen, J. L. (2010). Augmentation of space: Four dimensions of spatial experience of Google Earth. Space and Culture, 13(1), 121-133.

Karakuş, U., \& Oğuz, S. (2013). Sosyal bilgiler dersi coğrafya konularında Google Earth kullanımı ve öğretmen görüşleri. Uluslararası Avrasya Sosyal Bilimler Dergisi, 4(12), 110-125.
Koçak, F. (2013). Orta öğretim Coğrafya dersinde Google Earth'ün kullanımının değerlendirilmesi. Unpublished Master Thesesis. Karadeniz Technical University, Trabzon.

Köşker, N. (2012). Sınıf öğretmeni adaylarının mekânsal biliş yeterliliklerine ilişkin düşünceleri. Journal of World of Turks, 4(3), 161-173.

MoNE. (2005). Ilköğretim sosyal bilgiler dersi 4-5. sinıflar ögretim programı ve kılavuzu. Ankara: Talim Terbiye Kurulu Başkanlığı,

Öcal, A. (2007). Ilköğretim sosyal bilgiler dersinde 6. sınıf öğrencilerinin mekânsal biliş becerilerinin incelenmesi (Unpublished Dissertation). Gazi University, Ankara.

Öğütveren, M. (2014). Sosyal bilgiler 6. sınıf coğrafya konuIarının ögrretiminde Google Earth programının başarıya etkisi (Unpublished Master Thesesis). Giresun University, Giresun.

Özkaral, T. C. (2015). Ilkokul ve ortaokul düzeyinde sosyal bilgiler kapsamındaki öğretim programlarının karşılaştırmalı olarak incelenmesi (Unpublished Dissertation) Necmettin Erbakan University, Konya.

Patterson, T. C. (2007). Google Earth as a (not just) geography education tool. Journal of Geography, 106, 145-152.

Plano Clark, V. L., \& Creswell, J. W. (2015). Understanding research: A consumer guide. NJ: Pearson Education.

Plano Clark, V. L, Huddleston, C, C., Churchill, S., O'Neil Green, D. \& Garrett, A. (2008). Mixed methods approaches in family science research. Journal of Family Issues, 29(11), 1543-1566. https://doi. org/10.1177/0192513X08318251

Qiu, K. (2010). Geographic information technologies: an influence on the spatial ability of university students? (Unpublished Dissertation). Texas State University, USA

Ratinen, I., \& Keinonen, T. (2011). Student's use of Google Earth in problem-based geology learning. International Research in Geographical and Environmental Education, 20(4), 345-358.

Taylor, G. W., \& Ussher, J. M. (2001). Making sense of S\&M: A discourse analytic account. Sexualities, 4(3), 293314.

Thankachan, B., \& Franklin, T. (2013). Impact of Google Earth on student learning. International Journal of Humanities and Social Science, 3(21), 11-16.

Westgard, K. (2010). Google Earth in the middle school geography classroom: its impact on spatial literacy and place geography understanding of students (Unpublished Dissertation). University of North Dakota, USA.

Xiang, X. \& Liut, Y. (2017). Understanding 'change' through spatial thinking using Google Earth in secondary geography. Journal of Computer Assisted Learning, $33,65-78$

Yıldııım, A. \& Şimşek, H. (2013). Sosyal bilimlerde nitel araştırma yöntemleri. Ankara: Seçkin. 